\title{
Pengaruh Motivasi Kualitas, Motivasi Karir, Motivasi Ekonomi, Motivasi Sosial, Biaya Pendidikan pada Minat Mengikuti PPAk
}

\author{
I Made Bagus Angga Marta Permana ${ }^{1}$ \\ I Wayan Suartana
}

${ }^{1}$ Fakultas Ekonomi dan Bisnis Universitas Udayana (Unud), Bali, Indonesia email: angga.martapermana@gmail.com/ Tlp: 081999796734

${ }^{2}$ Fakultas Ekonomi dan Bisnis Universitas Udayana (Unud), Bali, Indonesia

\begin{abstract}
ABSTRAK
Tujuan penelitian ini untuk mengetahui pengaruh motivasi kualitas, motivasi karir, motivasi ekonomi, motivasi sosial dan biaya pendidikan pada minat mahasiswa mengikuti PPAk. Sampel penelitian ini adalah 61 responden dan menggunakan metode nonprobability sampling serta teknik purposive sampling. Metode pengumpulan data menggunakan kuesioner. Teknik analisis data yaitu Analisis Regresi Linier Berganda dalam menguji hipotesis. Kesimpulan dalam penelitian ini adalah variabel motivasi kualitas, motivasi karir, motivasi ekonomi dan motivasi sosial berpengaruh positif pada minat mahasiswa mengikuti PPAk. Ini berarti semakin tinggi motivasi yang dimiliki oleh mahasiswa maka semakin tinggi minat mengikuti PPAk. Berbeda dengan variabel biaya pendidikan yang berpengaruh negatif pada minat mahasiswa mengikuti PPAk yang berarti semakin tinggi biaya pendidikan, semakin rendah minat mengikuti PPAk.
\end{abstract}

Kata Kunci: Motivasi kualitas, motivasi karir, motivasi ekonomi, motivasi sosial, biaya pendidikan, minat mahasiswa mengikuti PPAk

\begin{abstract}
The purpose of this research is to know the influence of motivational qualities, economic motivation, career motivation, motivation and social costs of education on students 'interest to follow PPAk. The sample of this research is 61 respondents and use nonprobability sampling method and sampling purposive. Method of data collection using the questionnaire. Data analysis techniques, namely Multiple Linear regression analysis in testing the hypothesis. Conclusions in this study is the variable quality of motivation, career motivation, motivation of the economic and social motivations positive effect on students ' interest to follow PPAk. This means that the higher the motivation that is owned by the student then the higher interest follow PPAk. Unlike the variable tuition fees negatively influential on student interest follow PPAk which means the higher cost of education, the lower the interest follows a PPAk.

Keywords: Quality motivation, career motivation, economic motivation, social motivation, educational cost, interest of students follow PPAk
\end{abstract}




\section{PENDAHULUAN}

Jurusan Akuntansi adalah jurusan yang banyak minati mahasiswa saat ini dalam fakultas ekonomi. Orang yang berminat pada jurusan akuntansi mengalami peningkatan setiap tahunnya. Motivasi mereka memilih jurusan akuntansi karena adanya anggapan bahwa akuntan di masa yang akan datang memiliki peluang yang besar untuk bekerja di sebuah perusahaan atau organisasi (Wheeler, 1983). Pendidikan akuntansi sangat penting bagi seorang akuntan untuk meningkatkan keterampilan yang berkualitas serta profesionalisme dalam bersaing didalam dunia kerja. Pendidikan profesional akuntan yang berkelanjutan merupakan sebuah sarana dalam menjaga kompetensi serta kinerja seorang akuntan dalam menjalankan tugas profesionalnya serta untuk mempertahankan kepercayaan dari masyarakat.

Pendidikan Profesi Akuntansi (PPAk) adalah program yang ditujukan untuk lulusan sarjana jurusan akuntansi yang berkeinginan memperoleh gelar Akuntan. Tujuan PPAk untuk menghasilkan akuntan profesional dengan standarisasi kualitas akuntan di Indonesia. Berdasarkan Surat Keputusan Mendiknas No. 179/U/2001, lulusan sarjana strata satu (S1) jurusan akuntansi berkesempatan menempuh PPAk di perguruan tinggi yang telah ditunjuk oleh Direktorat Jenderal Pendidikan Tinggi. Perolehan gelar akuntan di Indonesia berawal dari UU No. 34 tahun 1954, gelar akuntan diberikan kepada seseorang yang menyelesaikan studi di perguruan tinggi yang ditunjuk berdasarkan peraturan perundang-undangan (Kementerian Kehakiman, 2017). Contoh perguruan tinggi yang memberlakukan undang-undang tersebut adalah Universitas 
Gajah Mada (UGM), Universitas Indonesia (UI) dan Sekolah Tinggi Akuntansi Negara (STAN), yang menamatkan gelar akuntan secara otomatis dan bagi lulusan dari universitas yang lain tidak dapat otomatis menghasilkan gelar akuntan kepada setiap lulusannya sehingga perlu mengikuti Ujian Negara Akuntansi (UNA) Dasar maupun Profesi. Machfoed (1998) menjelaskan proses perolehan gelar akuntan yang bersifat diskriminatif memiliki dua kelemahan yaitu munculnya diskriminasi dalam perolehan gelar akuntan serta tingkat profesionalisme para akuntan yang tidak merata dalam dunia kerja (Widyastuti \& Juliana, 2004).

Melihat hal tersebut membuat Menteri Keuangan Republik Indonesia mengeluarkan Peraturan Menteri Keuangan Nomor 25/PMK.01/2014 tentang Akuntan Beregister Negara (Menteri Keuangan Republik Indonesia, 2014). Peraturan tersebut kemudian dilakukan perubahan demi akuntan di Indonesia, maka dikeluarkanlah Peraturan Menteri Keuangan Republik Indonesia Nomor 216/PMK.01/2017 mengenai Akuntan Beregister yang disahkan pada tanggal 29 Desember 2017 (Menteri Keuangan Republik Indonesia, 2017). Perubahan tersebut dilakukan guna menyempurnakan pembinaan dan pengawasan terhadap profesi akuntan dan mendorong perkembangan profesi akuntan di Indonesia. Peraturan ini juga diharapkan agar gelar akuntan tidak didiskriminasi perguruan tinggi yang diberi hak istimewa oleh pemerintah.

PPAk merupakan program untuk mahasiswa jurusan akuntansi, karena program ini memberikan kontribusi bagi seseorang agar menjadi akuntan profesional. PPAk adalah pendidikan untuk sarjana jurusan akuntansi yang 
berkeingan memperoleh gelar akuntan (Raminten, 2012). Suatu profesi memiliki syarat agar dapat menjadi seseorang yang ahli di bidangnya dan bekerja secara profesional (Wyatt, 2003). Hingga saat ini banyak mahasiswa yang memilih jurusan Akuntansi, tetapi masih sedikit mahasiswa yang berminat untuk melanjutkan ke PPAk. Dikutip dari www.kompas.com pada 21 Maret 2016, jumlah akuntan di Indonesia masih minim dibandingkan dengan negara di Asia Tenggara lainnya. Jumlahnya yang minim tersebut dikarenakan masih kurangnya sertifikasi akuntan untuk menjadi akuntan yang profesional, masih kurangnya persiapan para akuntan dalam menghadapi Masyarakat Ekonomi ASEAN (MEA) dan minat untuk menjadi profesi akuntan yang masih rendah.

Universitas yang melaksanakan PPAk di Provinsi Bali adalah Fakultas Ekonomi dan Bisnis Universitas Udayana melalui ijin pelaksanaan dari Direktorat Jendral Pendidikan Tinggi. PPAk di Universitas Udayana beroperasi tanggal 1 April 2004 sampai saat ini dengan SK Perpanjangan Ijin Penyelenggaraan Program Pendidikan Profesi dari Kementerian Pendidikan dan Kebudayaan Direktorat Jenderal Pendidikan Tinggi. Suatu profesi memiliki beragam karakter serta erat kaitannya terhadap pengetahuan serta keahlian yang membedakan seseorang, berlandaskan ideologi pekerjaan, serta mempunyai peran yang baik dalam masyarakat (Saks, 2012). Tujuan dari program PPAk adalah menghasilkan akuntan yang memiliki keahlian di bidang profesi akuntan. Dalam peningkatan minat mahasiswa jurusan Akuntansi dalam mengikuti PPAk, diperlukan motivasi dari dalam diri mahasiswa tersebut. Motivasi berasal dari bahasa Latin "movere" yang artinya bergerak (Patrick et al., 2011). Motivasi adalah keadaan dalam 
pribadi seseorang yang mendorong keinginan individu untuk melakukan kegiatankegiatan tertentu guna mencapai tujuan (Dewi dan Setiawanta, 2014). Maka untuk mendorong minat dalam mengikuti PPAk, diperlukan peran motivasi kualitas, motivasi karir, motivasi ekonomi dan motivasi sosial. Biaya pendidikan juga diperlukan sebagai peran mahasiswa dalam mengikuti PPAk.

Teori hierarki kebutuhan Abraham Maslow adalah teori motivasi terkenal dan merupakan perintis dari teori motivasi yang bermunculan (Venugopalan, 2007: 38). Abraham Maslow (1954) mengemukakan mengenai teori motivasi Maslow yaitu Teori Hierarki Kebutuhan (Robbins dan Judge, 2015). Menurut Maslow, teori ini menjelaskan bahwa setiap individu memilki beragam kebutuhan yang dapat memengaruhi perilaku mereka (Lubis, 2014: 85). Teori ini juga menyebutkan bahwa apabila seseorang memutuskan menerima uang yang cukup untuk suatu pekerjaan dari sebuah organisasi tempatnya bekerja, maka uang tersebut tidak memiliki daya intensitasnya lagi. Suatu kebutuhan akan berhenti menjadi motivasi utama apabila kebutuhan individu tersebut mencapai puncaknya. Teori Motivasi Maslow ini akan memberikan penjelasan mengenai motivasi yang mendasari seseorang untuk bertindak dalam tingkatan yang berbeda dari kebutuhan seseorang tersebut. Teori Motivasi Maslow ini dapat digunakan sebagai dasar dalam mengetahui faktor yang memotivasi mahasiswa dalam mengikuti PPAk.

Motivasi kualitas yaitu dorongan di dalam diri seseorang agar dapat memperoleh dan meningkatkan kualitas diri serta dapat melaksanakan tugas dengan baik dan benar sesuai bidangnya (Berlinasari dan Erawati, 2017). Kualitas 
I Made Bagus Angga Marta Permana dan I Wayan Suartana. Pengaruh ...

merupakan istilah yang tidak mudah dipahami karena terdapat berbagai interprestasi tergantung pandangan pemangku kepentingan tersebut (Schindler et al., 2015). Dalam profesi akuntansi, elemen kualitas sangat diperhatikan baik dalam kinerja ataupun kemampuannya dalam bekerja. Salah satu alasan seseorang bisa termotivasi dalam pengambilan keputusan adalah dalam rangka meningkatkan kualitas seseorang dan prestasi (Tella, 2007). Peningkatan kemampuan dan kualitas seseorang harus didasari dengan minat yang kuat (Minan, 2011). Motivasi kualitas seseorang yang tinggi akan berpengaruh pada munculnya minat dalam mengembangkan potensi dalam dirinya dan nantinya berdampak pada meningkatnya sumber daya manusia dengan kualitas yang diinginkan (Mahmud, 2008).

Motivasi kualitas yang baik yang dialami oleh seseorang didukung oleh otonomi secara terstruktur dan memiliki keterlibatan secara emosional akan menciptakan lingkungan yang memungkinkan untuk memenuhi kebutuhan dasar mereka yakni kompetensi dan pengetahuan (Vansteenkiste et al., 2009). PPAk merupakan sarana bagi mahasiswa yang telah lulus dan ingin menjadi seorang akuntan yang profesional. Untuk meningkatkan kualitas diri dari mahasiswa, diperlukan motivasi yang dapat menggerakkan jiwa dan jasmani dengan cara menempuh PPAk. PPAk dapat meningkatkan kualitas seorang lulusan sarjana dalam bidang akuntansi (Kusumastuti \& Waluyo, 2013). Aryani dan Erawati (2016) serta Dyastari dan Yadnyana (2016) menunjukkan motivasi kualitas berpengaruh positif pada minat mahasiswa mengikuti PPAk. Melalui penjabaran tersebut, dirumuskan hipotesis sebagai berikut: 
$\mathrm{H}_{1}$ : Motivasi kualitas berpengaruh positif pada minat mahasiswa mengikuti PPAk

Karir merupakan sesuatu yang berasal dalam diri seseorang untuk melakukan sebuah usaha yang dapat meningkatkan kinerja dan berdampak pada tahap yang lebih baik lagi. Motivasi karir adalah keadaan yang membuat seseorang bergerak ke arah tujuannya dan berkaitan dengan lingkungan kerjanya (Lunenburg, 2011). Mahasiswa yang memilih karir menjadi seorang akuntan publik menginginkan keamanan kerja, kepuasan kerja, kemampuan akuntansi serta pengdapatan yang potensial di masa depan (Zyl dan Villiers, 2011).

Motivasi karir memiliki tiga karakter individu yaitu ketahanan karir, identitas karir dan wawasan karir (Noe et al., 1990). Tujuan adanya karir adalah untuk membantu menciptakan profesional sehingga mereka akan dapat memenuhi kebutuhan pengusaha potensial dengan demikian mereka akan memiliki kehidupan karir yang memuaskan (Kermis dan Kermis, 2013). PPAk merupakan institusi pendidikan yang dapat mempengaruhi perkembangan karir akuntan. PPAk juga membantu mahasiswa yang ingin mengembangkan keahlian dan kemampuannya dalam bidang akuntansi. Memiliki motivasi karir yang tinggi di masa depan, dapat meningkatkan minat seseorang untuk mengikuti PPAk. Hasil penelitian dari Berlinasari dan Erawati (2017), Andoko dan Sukhemi (2015), serta Kusumo dan Ahyani (2015) menunjukkan motivasi karir berpengaruh positif pada minat mahasiswa mengikuti PPAk. Kurniawan (2017) juga menunjukkan motivasi karir berpengaruh pada minat mahasiswa untuk mengikuti PPAk. Melalui penjabaran tersebut, dirumuskan hipotesis sebagai berikut: 
I Made Bagus Angga Marta Permana dan I Wayan Suartana. Pengaruh ...

$\mathrm{H}_{2}$ : Motivasi karir berpengaruh positif pada minat mahasiswa mengikuti PPAk.

Dalam teori Maslow, setiap orang memiliki beragam kebutuhan yang mempengaruhi perilaku mereka (Lubis, 2014: 85). Motivasi di diri seseorang dalam meningkatkan kemampuannya untuk memperoleh penghargaan financial (Widyastuti dan Juliana, 2004). Ekonomi berasal dari bahasa Yunani yaitu oikos (rumah tangga) dan nomos (peraturan, hukum) yang memiliki arti yaitu peraturan rumah tangga atau manajemen rumah tangga (Kopylov, 2013). Adanya motivasi ekonomi disebabkan tuntutan dalam memenuhi kebutuhan fisiologis, kebutuhan rasa aman, kebutuhan sosial, kebutuhan akan penghargaan dan kebutuhan akan aktualisasi diri. Penghargaan finansial merupakan salah satu bentuk sistem pengendalian manajemen dalam kebutuhan akan penghargaan (Dewi dan Setiawanta, 2014). Seseorang dapat memiliki motivasi secara ekonomis untuk memperbaiki hidup menggunakan keahlian yang ditetapkan (Sirgy et al., 2011). Hasil penelitian dari Aryani dan Erawati (2016) menunjukkan motivasi ekonomi berpengaruh positif pada minat mahasiswa mengikuti PPAk. Hasil penelitian dari Raminten (2012) juga menunjukkan motivasi ekonomi berpengaruh positif pada minat mahasiswa mengikuti PPAk. Melalui penjelasan tersebut, dirumuskan hipotesis sebagai berikut:

$\mathrm{H}_{3}$ : Motivasi ekonomi berpengaruh positif pada minat mahasiswa mengikuti PPAk.

Motivasi sosial merupakan motivasi yang didasari oleh kegiatan seseorang terhadap orang lain melalui sebuah reaksi dan dalam membuat pilihan selalu 
mempertimbangkan akibatnya terhadap orang lain (Martameh, 2012). Motivasi sosial dapat dikatakan juga sebagai dorongan dari dalam diri seseorang untuk melakukan suatu perbuatan yang memiliki nilai sosial serta untuk mendapatkan pengakuan maupun penghargaan dari lingkungan seseorang tersebut berada. Motivasi sosial dapat menyebabkan individu untuk berperilaku berbeda karena terkait dengan adanya motivasi ekonom yang melatarbelakanginya (Akerlof, 2006).

Membutuhkan kondisi dan situasi lingkungan yang baik saat bekerja sebagai akuntan. Seorang akuntan lebih dihargai dalam bekerja serta mendapatkan tempat yang baik dalam masyarakat memerlukan pengaruh nilai sosial. Nilai-nilai sosial ditunjukkan sebagai faktor yang mencerminkan kemampuan seseorang pada masyarakatnya, dengan kata lain nilai-nilai sosial adalah nilai seseorang dari sudut pandang orang lain di lingkungannya (Widyasari dan Laksito, 2010). Hasil penelitian yang dilakukan oleh Nurhayani (2012) serta Kusumo dan Ahyani (2015), motivasi sosial berpengaruh positif pada minat mahasiswa mengikuti PPAk. Melalui penjabaran tersebut, dirumuskan hipotesis sebagai berikut:

$\mathrm{H}_{4}$ : Motivasi sosial berpengaruh positif pada minat mahasiswa mengikuti PPAk.

Biaya pendidikan adalah pengeluaran finansial dari mahasiswa dalam memenuhi kebutuhan selama menjalani pendidikan dari awal hingga akhir masa pendidikan (Aryani dan Erawati, 2016). Pengeluaran ini dilakukan agar memperoleh manfaat yang dirasakan pada masa mendatang. Dalam hukum ekonomi, manusia berkeinginan memperoleh keuntungan setinggi-tingginya 
dengan pengeluaran serendah-rendahnya. Biaya pendidikan seseorang tidak hanya dilihat dari sisi jumlah yang dikeluarkan, melainkan dari sisi kemampuan dalam menyiapkan dan merasakan biaya yang dikeluarkan untuk kebutuhan pendidikan.

Masalah yang dihadapi dalam hal pendidikan adalah masih mahalnya biaya pendidikan yang harus dikeluarkan seseorang dalam menimba ilmu. Tentu hal ini menjadi penghambat bagi seseorang yang memiliki penghasilan rendah dan ingin menempuh pendidikan. Hasil Penelitian dari Kurniawan (2017) menunjukkan biaya pendidikan berpengaruh pada minat mahasiswa mengikuti PPAk. Berbeda dengan penelitian dari Aryani dan Erawati (2016) serta Raminten (2012), biaya pendidikan berpengaruh negatif pada minat mahasiswa mengikuti PPAk. Melalui uraian tersebut, hipotesis dirumuskan sebagai berikut:

$\mathrm{H}_{5}$ : Biaya pendidikan berpengaruh negatif pada minat mahasiswa mengikuti PPAk.

\section{METODE PENELITIAN}

Penelitian menggunakan metode penelitian kuantitatif berbentuk asosiatif. Lokasi penelitian dilakukan di Fakultas Ekonomi dan Bisnis Universitas Udayana, Denpasar. Objek penelitian yaitu minat mahasiswa mengikuti PPAk yang dikaitkan oleh motivasi kualitas, motivasi karir, motivasi ekonomi, motivasi sosial dan biaya pendidikan. Variabel bebas pada penelitian ini yaitu motivasi kualitas (X1), motivasi karir (X2), motivasi ekonomi (X3), motivasi sosial (X4) dan biaya pendidikan (X5). Variabel terikat adalah minat mahasiswa mengikuti PPAk (Y). 
Populasi penelitian yaitu mahasiswa akuntansi program S1 Reguler angkatan 2014 di Fakultas Ekonomi dan Bisnis Universitas Udayana dengan jumlah 203 orang. Teknik yang digunakan dalam menentukan sampel pada penelitian ini adalah nonprobability sampling dan teknik samplingnya adalah purposive sampling. Kriteria sampel dalam penelitian ini yaitu (1) mahasiswa jurusan akuntansi program S1 Fakultas Ekonomi dan Bisnis Universitas Udayana angkatan 2014 dengan status aktif sebagai mahasiswa, (2) telah menempuh mata kuliah Pengauditan 1, Pengauditan 2 dan Pratikum Audit \& PDE. Agar jumlah sampel yang digunakan representatif, selanjutnya digunakan rumus Slovin dengan nilai kritis sebesar 0,10 .

$$
\frac{N}{1+N\left(e^{2}\right)}=\frac{153}{1+153\left(0,10^{2}\right)}=60,47
$$

Berdasarkan perhitungan tersebut, maka jumlah sampel yang digunakan dalam penelitian ini adalah sebanyak 60,47 yang dibulatkan keatas menjadi 61 responden.

Metode pengumpulan data adalah menggunakn survey dengan memberikan kuesioner kepada mahasiswa jurusan akuntansi Fakultas Ekonomi dan Bisnis Universitas Udayana secara langsung. Skala pengukuran yang digunakan yaitu skala Likert. Alasan digunakannya skala Likert 4 poin dalam penelitian ini adalah untuk menghindari jawaban responden yang ambigu karena adanya pernyataan "ragu-ragu" atau netral yang timbul dari nilai tengah. Jenis data dalam penelitian ini menggunakan data kuantitatif yaitu hasil dari jawaban yang terdapat pada kuesioner. Penelitian ini menggunakan sumber data primer dan data sekunder. Sumber data primer adalah jawaban kuesioner dan sumber data 
I Made Bagus Angga Marta Permana dan I Wayan Suartana. Pengaruh ...

sekundernya adalah data mahasiswa jurusan Akuntansi regular angkatan 2014 yang didapatkan pada website Integrated Management Information System the Strategic of UNUD (IMISSU) serta gambaran umum program PPAk Fakultas Ekonomi dan Bisnis Universitas Udayana pada website PPAk Fakultas Ekonomi dan Bisnis Universitas Udayana.

Instrumen penelitian digunakan untuk mengukur nilai variabel yang diteliti (Sugiyono, 2014: 131). Instrumen yang digunakan untuk mengukur adalah uji validitas dan uji reliabilitas. Dilakukan juga uji asumsi klasik yaitu uji normalitas, uji multikolonearitas dan uji heteroskedastisitas. Teknik analisis data dalam penelitian ini meliputi statistik deskriptif, analisis regresi linier berganda, koefisien determinasi $\left(\mathrm{R}^{2}\right)$, uji kelayakan model (Uji F) dan uji hipotesis (Uji t).

\section{HASIL DAN PEMBAHASAN}

Penelitian ini dilakukan untuk mendapat bukti empiris pengaruh dari motivasi kualitas, motivasi karir, motivasi ekonomi, motivasi sosial dan biaya pendidikan pada minat mahasiswa mengikuti PPAk. Penelitian ini menggunakan data primer yaitu kuesioner untuk memperoleh data. Penelitian ini menggunakan teknik analisis data yaitu regresi linier berganda. Jumlah kuesioner yang disebar pada mahasiswa jurusan akuntansi Fakultas Ekonomi dan Bisnis Universitas Udayana angkatan 2014 adalah sebanyak 61 kuesioner dan semuanya kembali dengan lengkap.

Statistik deskriptif memberikan informasi mengenai karakter dari variabel penelitian seperti nilai minimum, nilai maksimum, nilai rata-rata, dan standar deviasi pada data berskala interval. 
ISSN: 2302-8556

E-Jurnal Akuntansi Universitas Udayana

Vol.25.1.Oktober (2018): 214 -240

DOI: https://doi.org/10.24843/EJA.2018.v25.i01.p09

Tabel 1.

Hasil Statistik Deskriptif

\begin{tabular}{lcrrrr}
\hline \multicolumn{1}{c}{ Variabel } & N & Minimum & Maximum & Mean & $\begin{array}{c}\text { Deviasi } \\
\text { Standar }\end{array}$ \\
\hline Motivasi Kualitas $\left(\mathrm{X}_{1}\right)$ & 61 & 9,15 & 25,34 & 20,5867 & 5,27729 \\
\hline Motivasi Karir $\left(\mathrm{X}_{2}\right)$ & 61 & 11,24 & 29,29 & 23,3731 & 5,83383 \\
\hline Motivasi Ekonomi $\left(\mathrm{X}_{3}\right)$ & 61 & 8,32 & 24,85 & 19,7287 & 5,24999 \\
\hline Motivasi Sosial $\left(\mathrm{X}_{4}\right)$ & 61 & 6,18 & 20,56 & 16,4498 & 4,29706 \\
\hline Biaya Pendidikan $\left(\mathrm{X}_{5}\right)$ & 61 & 4,00 & 19,17 & 11,9764 & 3,56693 \\
\hline Minat Mahasiswa Mengikuti & 61 & 7,06 & 20,68 & 16,5380 & 4,40094 \\
PPAk (Y) & & & & & \\
\hline
\end{tabular}

Sumber: Data diolah, 2018

Tabel 1 menunjukkan jumlah kuesioner yang diolah sebanyak 61 kuesioner. Variabel motivasi kualitas $\left(\mathrm{X}_{1}\right)$ memiliki nilai minimum sebesar 9,15 , nilai maksimum sebesar 25,34, nilai mean sebesar 20,5867, dan standar deviasinya sebesar 5,27729. Variabel motivasi karir $\left(\mathrm{X}_{2}\right)$ memiliki nilai minimum sebesar 11,24, nilai maksimum sebesar 29,29, nilai mean sebesar 23,3731, dan standar deviasinya sebesar 5,83383. Variabel motivasi ekonomi $\left(\mathrm{X}_{3}\right)$ memiliki nilai minimum sebesar 8,32 , nilai maksimum sebesar 24,85 , nilai mean sebesar 19,7287, dan standar deviasinya sebesar 5,24999. Motivasi sosial $\left(\mathrm{X}_{4}\right)$ memiliki nilai minimum sebesar 6,18 , nilai maksimum sebesar 20,56, nilai mean sebesar 16,4498, dan standar deviasinya sebesar 4,29706. Biaya pendidikan $\left(\mathrm{X}_{5}\right)$ memiliki nilai minimum sebesar 4,00, nilai maksimum sebesar 19,17 , nilai mean sebesar 11,9764, dan standar deviasinya sebesar 3,56693. Minat mahasiswa mengikuti PPAk (Y) memiliki nilai minimum sebesar 7,06, nilai maksimum sebesar 20,68, nilai mean sebesar 16,5380, dan standar deviasinya sebesar 4,40094. 
I Made Bagus Angga Marta Permana dan I Wayan Suartana. Pengaruh ...

Untuk menghitung hubungan antara skor setiap pernyataan dengan total skor dan diperoleh nilai Pearson Correlationm, dilakukan uji validitas. Semua instrumen penelitian untuk mengukur variabel penelitian ini memiliki nilai koefisien korelasi diatas 0,3 sehingga keseluruhan indikator dinyatakan valid.

Uji reliabilitas menunjukkan suatu pengukuran kembali terhadap gejala yang sama. Instrumen yang reliabel adalah instrumen yang digunakan beberapa kali untuk mengukur objek yang sama dan akan menghasilkan data atau jawaban yang sama pula.

Tabel 2.

Hasil Uji Reliabilitas

\begin{tabular}{lcc}
\hline \multicolumn{1}{c}{ Variabel } & Cronbach's Alpha & Keterangan \\
\hline Motivasi Kualitas $\left(\mathrm{X}_{1}\right)$ & 0,935 & Reliabel \\
\hline Motivasi Karir $\left(\mathrm{X}_{2}\right)$ & 0,929 & Reliabel \\
\hline Motivasi Ekonomi $\left(\mathrm{X}_{3}\right)$ & 0,952 & Reliabel \\
\hline Motivasi Sosial $\left(\mathrm{X}_{4}\right)$ & 0,923 & Reliabel \\
\hline Biaya Pendidikan $\left(\mathrm{X}_{5}\right)$ & 0,921 & Reliabel \\
\hline $\begin{array}{l}\text { Minat Mahasiswa Mengikuti } \\
\text { PPAk }(\mathrm{Y})\end{array}$ & 0,942 & Reliabel
\end{tabular}

Sumber: Data diolah, 2018

Instrumen katakan reliabel bila memperoleh nilai Cronbach's Alpha lebih dari 0,70 . Tabel 2 menunjukkan setiap variabel memiliki nilai koefisien Cronbach's Alpha lebih dari 0,70. Seluruh variabel penelitian ini adalah reliabel.

Untuk menguji variabel pengganggu atau residual memiliki distribusi normal dalam model regresi, dilakukan uji normalitas (Ghozali, 2016: 154). Pengujian normalitas data dalam penelitian ini menggunakan statistic KolmogrovSmirnov. Distribusi data dinyatakan normal jika nilai probabilitas pengujian lebih besar 0,05. 
ISSN: 2302-8556

E-Jurnal Akuntansi Universitas Udayana

Vol.25.1.Oktober (2018): 214 -240

DOI: https://doi.org/10.24843/EJA.2018.v25.i01.p09

Tabel 3.

Hasil Uji Normalitas

\begin{tabular}{llr}
\hline & & Unstandardized Residual \\
\hline N & & 61 \\
\hline Normal Parameters & &, 0000000 \\
& Mean & 1,89374175 \\
\cline { 2 - 3 } & Std. Deviation &, 088 \\
\hline Most Extreme Differences & Absolute &, 088 \\
\cline { 2 - 3 } & Positive &,- 062 \\
\cline { 2 - 3 } & Negative &, 088 \\
\hline Test Statistic & &, $200^{\mathrm{c}, \mathrm{d}}$ \\
\hline Asymp. Sig. (2-tailed) & & \\
\hline
\end{tabular}

Sumber: Data diolah, 2018

Variabel bebas dan variabel terikat dalam Tabel 3 memiliki nilai signifikansi sebesar 0,200 lebih besar dari 0,05. Hal ini menunjukkan variabel motivasi kualitas, motivasi karir, motivasi ekonomi, motivasi sosial, biaya pendidikan, dan minat mengikuti PPAk adalah berdistribusi normal.

Uji multikolinearitas yaitu menguji adanya hubungan antara variabel bebas dalam model regresi (Ghozali, 2016: 103). Keberadaan multikolinearitas dalam model regresi adalah melihat nilai tolerance atau Variance Inflation Factor (VIF). Jika nilai tolerance lebih besar dari $10 \%$ atau VIF kurang dari 10 , maka dapat dikatakan model telah bebas dari masalah multikolinearitas (Ghozali, 2016: 104). 
Tabel 4.

Hasil Uji Multikolinearitas

\begin{tabular}{lcc}
\hline \multirow{2}{*}{ Variabel } & \multicolumn{2}{c}{ Collinearity Statistics } \\
\cline { 2 - 3 } & Tolerance & VIF \\
\hline Motivasi Kualitas $\left(\mathrm{X}_{1}\right)$ & 0,460 & 2,173 \\
\hline Motivasi Karir $\left(\mathrm{X}_{2}\right)$ & 0,524 & 1,909 \\
\hline Motivasi Ekonomi $\left(\mathrm{X}_{3}\right)$ & 0,536 & 1,865 \\
\hline Motivasi Sosial $\left(\mathrm{X}_{4}\right)$ & 0,534 & 1,872 \\
\hline Biaya Pendidikan $\left(\mathrm{X}_{5}\right)$ & 0,580 & 1,723 \\
\hline
\end{tabular}

Sumber: Data diolah, 2018

Tabel 4 menunjukkan hasil uji multikolinearitas yang dimana masingmasing variabel bebas memiliki nilai tolerance lebih besar dari 10\% dan nilai VIF lebih kecil dari 10. Disimpulkan bahwa model regresi dalam penelitian ini tidak ada multikolinearitas antar variabel bebas.

Uji heteroskedastisitas yaitu menguji ketidaksamaan variance dari satu pengamatan ke pengamatan yang lain dalam model regresi (Ghozali, 2016: 134). Jika variance dari residual satu pengamatan ke pengamatan lain tetap (homoskedastisitas) atau tidak terjadi perbedaan antar pengamatan (heteroskedastisitas) maka model regresi tersebut baik. Uji yang digunakan dalam penelitian ini adalah uji Glejser. Jika nilai signifikansinya di atas 5\%, maka dapat disimpulkan mode regresi tidak mengandung adanya heteroskedastisitas.

Tabel 5.

Hasil Uji Heteroskedastisitas

\begin{tabular}{clcl}
\hline No & \multicolumn{1}{c}{ Variabel } & Sig. & \multicolumn{1}{c}{ Keterangan } \\
\hline 1 & Motivasi Kualitas $\left(\mathrm{X}_{1}\right)$ & 0,137 & Bebas Heteroskedastisitas \\
\hline 2 & Motivasi Karir $\left(\mathrm{X}_{2}\right)$ & 0,161 & Bebas Heteroskedastisitas \\
\hline 3 & Motivasi Ekonomi $\left(\mathrm{X}_{3}\right)$ & 0,637 & Bebas Heteroskedastisitas \\
\hline 4 & Motivasi Sosial $\left(\mathrm{X}_{4}\right)$ & 0,255 & Bebas Heteroskedastisitas \\
\hline 5 & Biaya Pendidikan $\left(\mathrm{X}_{5}\right)$ & 0,473 & Bebas Heteroskedastisitas \\
\hline
\end{tabular}

Sumber: Data diolah, 2018 
Tabel 5 menunjukkan tingkat signifikansi dari setiap variabel bebas lebih besar 0,05, maka disimpulkan bahwa model regresi bebas dari heteroskedastisitas.

Analisis regresi linear berganda dilakukan untuk mengetahui hubungan antara lebih dari dua variabel atau lebih, yaitu pengaruh motivasi kualitas, motivasi karir, motivasi ekonomi, motivasi sosial, biaya pendidikan pada minat mahasiswa mengikuti PPAk

Tabel 6

Hasil Analisis Regresi Linear Berganda

\begin{tabular}{|c|c|c|c|c|c|}
\hline \multirow[t]{2}{*}{ Variabel } & \multicolumn{2}{|c|}{$\begin{array}{c}\text { Unstandardized } \\
\text { Coefficients }\end{array}$} & \multirow{2}{*}{$\begin{array}{c}\begin{array}{c}\text { Standardized } \\
\text { Coefficients }\end{array} \\
\text { Beta }\end{array}$} & \multirow[t]{2}{*}{$\mathbf{T}$} & \multirow[t]{2}{*}{ Sig. } \\
\hline & B & Std. Error & & & \\
\hline (Constant) & 4,310 & 2,468 & & 1,746 & 0,086 \\
\hline Motivasi Kualitas $\left(\mathrm{X}_{1}\right)$ & 0,223 & 0,071 & 0,267 & 3,122 & 0,003 \\
\hline Motivasi Karir $\left(\mathrm{X}_{2}\right)$ & 0,184 & 0,060 & 0,244 & 3,045 & 0,004 \\
\hline Motivasi Ekonomi $\left(\mathrm{X}_{3}\right)$ & 0,148 & 0,066 & 0,176 & 2,223 & 0,030 \\
\hline Motivasi Sosial $\left(\mathrm{X}_{4}\right)$ & 0,220 & 0,081 & 0,215 & 2,708 & 0,009 \\
\hline Biaya Pendidikan $\left(\mathrm{X}_{5}\right)$ & $-0,267$ & 0,094 & $-0,216$ & $-2,840$ & 0,006 \\
\hline Adjusted $R^{2}$ & & & & & 0,798 \\
\hline $\mathrm{R}^{2}$ & & & & & 0,815 \\
\hline $\mathrm{F}$ & & & & & 48,408 \\
\hline Sig. F & & & & & 0,000 \\
\hline
\end{tabular}

Sumber: Data diolah, 2018

Nilai koefisien regresi dari variabel bebas serta nilai konstanta variabel terikat ditunjukkan pada Tabel 6. Diperoleh persamaan regresi linear berganda sebagai berikut.

$$
Y=4,310+0,223\left(X_{1}\right)+0,184\left(X_{2}\right)+0,148\left(X_{3}\right)+0,220\left(X_{4}\right)-0,267\left(X_{5}\right)+\varepsilon
$$


Nilai koefisien determinasi $\left(\mathrm{R}^{2}\right)$ menunjukkan kemampuan variabel independen dalam menerangkan variasi variabel dependen. Besarnya nilai koefisien determinasi ditunjukkan dengan nilai Adjusted $\mathrm{R}^{2}$ yaitu sebesar 0,798 atau 79,8 persen. Nilai koefisien tersebut memiliki arti yaitu sebesar 79,8 persen minat mahasiswa mengikuti PPAk dipengaruhi oleh variabel motivasi kualitas, motivasi karir, motivasi ekonomi, motivasi sosial, dan biaya pendidikan, sedangkan sisanya sebesar 20,2 persen dipengaruhi oleh faktor lain di luar model penelitian.

Uji kelayakan model (Uji F) dilakukan untuk mengetahui kelayakan suatu model regresi berganda serta untuk mengetahui apakah model penelitian dapat digunakan dalam memprediksi variabel dependen. Bila nilai signifikansi $\mathrm{F}<\alpha$ (alpha) 0,05 maka model penelitian ini layak. Berdasarkan tabel 4.9, nilai signifikansi $\mathrm{F}$ sebesar 0,000 lebih kecil dari 5 persen yang memiliki arti variabel bebas pada model penelitian dapat untuk digunakan.

Untuk mengetahui pengaruh setiap variabel bebas terhadap variabel terikat, dilakukan uji t (Ghozali, 2016:97). Tingkat signifikansi ( $\alpha$ ) yang digunakan adalah sebesar 5 persen $(0,05)$. Jika tingkat signifikansi $\mathrm{t} \leq \alpha, \mathrm{H}_{1}$ diterima dan bila tingkat signifikansi $\mathrm{t}>\alpha, \mathrm{H}_{1}$ ditolak. Tabel 4.9 menunjukkan tingkat signifikansi motivasi kualitas sebesar $0,003<$ dari $\alpha=0,05, \mathrm{H}_{1}$ diterima yang membuktikan motivasi kualitas dari mahasiswa jurusan akuntansi yang semakin tinggi maka minat mahasiswa mengikuti PPAk juga semakin tinggi. Tingkat signifikansi motivasi karir sebesar 0,004 lebih kecil dari $\alpha=0,05, \mathrm{H}_{2}$ diterima yang membuktikan motivasi karir dari mahasiswa jurusan akuntansi yang 
semakin tinggi maka minat mahasiswa mengikuti PPAk juga semakin tinggi. Tingkat signifikansi motivasi ekonomi sebesar 0,030 lebih kecil dari $\alpha=0,05, \mathrm{H}_{3}$ diterima yang membuktikan motivasi ekonomi dari mahasiswa jurusan akuntansi yang semakin tinggi maka minat mahasiswa mengikuti PPAk juga semakin tinggi. Tingkat signifikansi motivasi sosial sebesar 0,009 lebih kecil dari $\alpha=0,05, \mathrm{H}_{4}$ diterima yang membuktikan motivasi sosial dari mahasiswa jurusan akuntansi yang semakin tinggi maka minat mahasiswa mengikuti PPAk juga semakin tinggi. Tingkat signifikansi biaya pendidikan sebesar 0,006 lebih kecil dari $\alpha=0,05, \mathrm{H}_{5}$ diterima yang membuktikan biaya pendidikan yang semakin tinggi maka minat mahasiswa mengikuti PPAk akan semakin rendah.

Pembahasan dari hasil pengujian hipotesis yang telah diakukan adalah motivasi kualitas berpengaruh positif pada minat mahasiswa mengikuti PPAk. Pada Tabel 4.9, nilai t hitung variabel motivasi kualitas sebesar 3,122, nilai signifikansi uji t sebesar 0,003 yang lebih kecil dari $\alpha=0,05$ dan nilai koefisien regresi sebesar 0,223 . Uji statistik tersebut menunjukkan bahwa $\mathrm{H}_{1}$ diterima yang artinya semakin kuat dorongan dari dalam diri mahasiswa dalam meningkatkan kualitas diri serta kemampuannya dibidangnya, maka minat mahasiswa dalam mengikuti PPAk juga akan meningkat. Hasil penelitian ini juga sesuai dengan teori motivasi Maslow yang menyatakan bahwa motivasi seseorang dapat didorong akibat adanya keinginan untuk memenuhi kebutuhan akan aktualisasi diri. Penelitian dari Kusumastuti dan Waluyo (2013) menyatakan motivasi kualitas berpengaruh positif pada minat mahasiswa mengikuti PPAk. Penelitian dari Berlinasari dan Erawati (2017) juga mendukung bahwa motivasi kualitas 
berpengaruh positif pada minat mahasiswa untuk mengikuti PPAk. Minat yang tinggi dari mahasiswa untuk mengikuti PPAk dipengaruhi keinginan untuk meningkatkan kualitas serta kemampuan dibidang yang ditekuni. PPAk merupakan sarana yang masih diyakini oleh mahasiswa dalam meningkatkan kualitas serta dapat memberikan dampak efektivitas dan efisien yang baik sebagai seorang akuntan.

Motivasi karir berpengaruh positif pada minat mahasiswa mengikuti PPAk. Pada Tabel 4.9, nilai t hitung variabel motivasi karir sebesar 3,045, nilai signifikansi uji t sebesar 0,004 yang lebih kecil dari $\alpha=0,05$ dan nilai koefisien regresi sebesar 0,184 . Uji statistik tersebut menunjukkan bahwa $\mathrm{H}_{2}$ diterima yang artinya semakin kuat motivasi mahasiswa dalam meningkatkan kemampuan pribadi dalam memperoleh karir yang baik, maka minat mahasiswa dalam mengikuti PPAk juga akan meningkat. Hasil penelitian ini juga sejalan dengan teori motivasi yang dikemukakan oleh Maslow yang menyatakan bahwa motivasi seseorang dapat didorong akibat adanya keinginan untuk memenuhi kebutuhan akan penghargaan yang berkaitan dengan reputasi dan prestasi. Penelitian ini sejalan dengan penelitian dari Vesperalis dan RM (2017), motivasi karir berpengaruh positif pada minat mahasiswa mengikuti PPAk. Dyastari dan Yadnyana (2016) juga menunjukkan motivasi karir berpengaruh positif pada minat mahasiswa mengikuti PPAk. Tingginya minat dari dalam diri mahasiswa untuk mengikuti PPAk dipengaruhi oleh keinginan untuk dapat meningkatkan kemampuan pribadi dan memperoleh karir yang baik dalam bidang yang ditekuni. Sarana yang dapat meningkatkan karir yang baik untuk masa depan adalah PPAk. 
Hipotesis ketiga $\left(\mathrm{H}_{3}\right)$ diperoleh motivasi ekonomi berpengaruh positif pada minat mahasiswa mengikuti PPAk. Berdasarkan Tabel 4.9, nilai t hitung variabel motivasi kualitas sebesar 2,223, nilai signifikansi uji t sebesar 0,030 yang lebih kecil dari $\alpha=0,05$ dan nilai koefisien regresi sebesar 0,148 . Uji statistik tersebut menunjukkan bahwa $\mathrm{H}_{3}$ diterima yang artinya semakin kuat dorongan motivasi ekonomi mahasiswa untuk mencapai penghargaan finansial yang diinginkan maka semakin tinggi minat mahasiswa mengikuti PPAk. Adanya tuntutan dalam memenuhi kebutuhan fisiologis, kebutuhan rasa aman, kebutuhan sosial, kebutuhan akan penghargaan dan kebutuhan akan aktualisasi diri juga semakin menguatkan motivasi ekonomi tersebut. Teori Maslow menyatakan setiap individu memiliki beragam kebutuhan yang mempengaruhi perilaku mereka (Lubis, 2014: 85). Dengan adanya motivasi ekonomi akan membuat seseorang akan melakukan kegiatan ekonomi agar mendapatkan kepuasan materiil. Hasil penelitian ini sejalan dengan penelitian yang dilakukan oleh Kurniawan (2017) serta Berlinasari dan Erawati (2017) yang membuktikan motivasi ekonomi berpengaruh positif pada minat mahasiswa mengikuti PPAk. Motivasi ekonomi yang semakin kuat dari mahasiswa dalam memperoleh penghasilan dan kebutuhan yang lebih besar, semakin tinggi minat mahasiswa mengikuti PPAk.

Hipotesis keempat $\left(\mathrm{H}_{4}\right)$ diperoleh motivasi sosial berpengaruh positif pada minat mahasiswa mengikuti PPAk. Berdasarkan Tabel 4.9, nilai t hitung variabel motivasi kualitas sebesar 2,708, nilai signifikansi uji t sebesar 0,009 yang lebih kecil dari $\alpha=0,05$ dan nilai koefisien regresi sebesar 0,220. Uji statistik tersebut menunjukkan bahwa $\mathrm{H}_{4}$ diterima yang artinya motivasi sosial yang 
semakin kuat, minat mahasiswa untuk mengikuti PPAk juga semakin tinggi. Teori motivasi Maslow mengemukakan bahwa setiap orang memerlukan dorongan dalam memenuhi kebutuhan sosial. Hal teserbut dapat berupa kepuasan dalam menjalin hubungan dengan orang lain atau dalam suatu kelompok. Adanya motivasi sosial akan berdampak pada kinerja seorang akuntan yang akan merasa lebih dihargai dan mendapat tempat di masyarakat. Pekerjaan seorang akuntan membutuhkan lingkungan dan situasi yang baik. Perhatian seorang akuntan pada lingkungannya juga akan meningkatkan nilai instrinsik dan kinerja. Hasil penelitian yang dilakukan oleh Kusumo dan Ahyani (2015) menunjukkan motivasi sosial berpengaruh positif pada minat mahasiswa mengikuti PPAk. Penelitian dari Nurhayani (2012) diperoleh motivasi sosial berpengaruh positif pada minat mahasiswa mengikuti PPAk. Semakin kuat motivasi sosial mahasiswa dalam menjalin hubungan dengan orang lain ataupun dengan lingkungan, maka semakin tinggi minat mahasiswa mengikuti PPAk.

Hipotesis kelima $\left(\mathrm{H}_{5}\right)$ menyatakan biaya pendidikan berpengaruh negatif pada minat mahasiswa mengikuti PPAk. Berdasarkan Tabel 4.9, nilai t hitung variabel biaya pendidikan sebesar -2,840, nilai signifikansi uji t sebesar 0,006 yang lebih kecil dari $\alpha=0,05$ dan nilai koefisien regresi sebesar $-0,267$. Uji statistik tersebut menunjukkan bahwa $\mathrm{H}_{5}$ diterima yang artinya, tingginya biaya pendidikan, maka minat mahasiswa untuk mengikuti PPAk akan semakin rendah. Mahalnya biaya yang dikeluarkan dalam menempuh PPAk akan menyulitkan mahasiswa yang ingin menempuh profesi akuntansi tetapi memiliki penghasilan yang rendah. Adanya hambatan seperti ini akan mengurangi minat mahasiswa 
mengikuti PPAk bahkan akan mengurangi akuntan khususnya di Indonesia. Hasil penelitian yang dilakukan oleh Aryani dan Erawati (2016) menyatakan biaya pendidikan berpengaruh negatif pada minat mahasiswa mengikuti PPAk. Penelitian dari Raminten (2012) juga diperoleh biaya pendidikan berpengaruh negatif pada minat mahasiswa mengikuti PPAk. Biaya pendidikan yang semakin tinggi, maka minat mahasiswa mengikuti PPAk juga semakin rendah.

Penelitian ini mampu untuk memberikan informasi mengenai dampak peran Teori Motivasi Maslow terhadap motivasi kualitas, motivasi karir, motivasi ekonomi, motivasi sosial, dan biaya pendidikan pada minat mahasiswa mengikuti PPAk. Hasil penelitian ini untuk pertimbangan dalam melakukan peningkatan minat mahasiswa akuntansi Program S1 dalam mengikuti PPAk (PPAk) serta dapat memberikan informasi mengenai faktor yang dapat menghambat minat mahasiswa mengikuti PPAk.

\section{SIMPULAN}

Hasil analisis dan pembahasan yang telah dilakukan pada bab-bab sebelumnya, ditarik simpulan bahwa Motivasi kualitas berpengaruh positif pada minat mahasiswa mengikuti PPAk. Kuatnya motivasi dari mahasiswa dalam meningkatkan kualitas diri dan kemampuan dibidangnya, minat mahasiswa mengikuti PPAk juga akan meningkat. Motivasi karir berpengaruh positif pada minat mahasiswa mengikuti PPAk. Kuatnya dorongan dari diri mahasiswa untuk meningkatkan kemampuan pribadi serta untuk memperoleh karir yang baik, maka minat mahasiswa dalam mengikuti PPAk juga akan meningkat. Motivasi ekonomi berpengaruh positif pada minat mahasiswa mengikuti PPAk. Kuatnya dorongan 
motivasi ekonomi untuk memperoleh penghargaan finansial yang diinginkan, minat mahasiswa mengikuti PPAk semakin tinggi. Motivasi sosial berpengaruh positif pada minat mahasiswa mengikuti PPAk. Semakin kuat motivasi sosial mahasiswa dalam menjalin hubungan dengan orang lain ataupun dengan lingkungan, minat mahasiswa mengikuti PPAk juga semakin tinggi. Biaya pendidikan berpengaruh negatif pada minat mahasiswa mengikuti PPAk. Semakin tinggi biaya pendidikan, minat mahasiswa untuk mengikuti PPAk akan semakin rendah.

Saran yang dapat diberikan dalam penelitian ini adalah (1) Peneliti selanjutnya diharapkan dapat memperluas ruang lingkup responden seperti menggunakan responden dari mahasiswa jurusan akuntansi di luar Universitas Udayana. Hal ini dapat memberikan informasi kepada mahasiswa di luar Universitas Udayana mengenai program PPAk. (2) Peneliti yang ingin melakukan penelitian sejenis disarankan agar menambah variabel seperti motivasi gelar, motivasi mencari ilmu, dan lingkungan keluarga, yang dapat mempengaruhi minat mahasiswa mengikuti PPAk.

\section{REFERENSI}

Akerlof, R. J. (2006). A Theory of Social Motivation. Unpublished Manuscript, Cambridge, $M A$.

Andoko, C. Y., \& Sukhemi. (2015). Pengaruh Motivasi Terhadap Minat Mahasiswa Akuntansi untuk Mengikuti PPAk (PPAk). Akmenika: Jurnal Akuntansi Dan Manajemen, 12(2), 652-659.

Aryani, N. P. D., \& Erawati, N. M. A. (2016). Pengaruh Motivasi Kualitas, Karir, Ekonomi, dan Biaya Pendidikan pada Minat Mahasiswa Mengikuti PPAk. EJurnal Akuntansi Universitas Udayana, 16(1), 362-387. 
Berlinasari, M., \& Erawati, N. M. A. (2017). Pengaruh Motivasi, Biaya Pendidikan dan Lama Pendidikan pada Minat Mahasiswa Akuntansi Mengikuti PPAk. E-Jurnal Akuntansi Universitas Udayana, 21(1), 447-476.

Dewi, I. F., \& Setiawanta, Y. (2014). Pengaruh Persepsi dan Motivasi Mahasiswa Jurusan Akuntansi yang Sedang Mengambil Skripsi Terhadap Peminatan Karir dalam Bidang Perpajakan (Studi Empiris pada Mahasiswa Akuntansi Universitas Dian Nuswantoro). Skripsi Fakultas Ekonomi Dan Bisnis Universitas Dian Nuswantoro.

Dyastari, N. P. S., \& Yadnyana, I. K. (2016). Pengaruh Motivasi pada Minat Mahasiswa Non Akuntansi untuk Mengikuti PPAk. E-Jurnal Akuntansi Universitas Udayana, 16(1), 333-361.

Ghozali, I. (2016). Aplikasi Analisis Multivariete dengan Program IMB SPSS 23 (8th ed.). Semarang: Badan Penerbit Universitas Diponegoro.

Kermis, G., \& Kermis, M. (2013). Professional Presence and Soft Skills: a Role for Accounting Education. Journal of Instructional Pedagogies, 14(8), 1-10.

Kopylov, A. V. (2013). Aristotle Economy and Modern Times Annotation. Middle-East Journal of Scientific Research, 14(8), 1070-1078.

Kurniawan, D. H. (2017). Analisis Pengaruh Motivasi Karir, Motivasi Ekonomi, Pengalaman Kerja dan Biaya Pendidikan pada Minat Mengikuti PPAk (Studi Empiris pada Alumni S1 Jurusan Akuntansi). Doctoral Disstertation Universitas Muhammadiyah Surakarta.

Kusumastuti, R., \& Waluyo, I. (2013). Pengaruh Motivasi dan Pengetahuan UU No.5 Tahun 2011 Tentang Akuntan Publik Terhadap Minat Mahasiswa Akuntansi Mengikuti PPAk (PPAk). Jurnal Nominal, 2(2), 1-30.

Kusumo, D., \& Ahyani, F. (2015). Pengaruh Motivasi Terhadap Minat Mahasiswa Akuntansi untuk Mengikuti PPAk (PPAk) (Studi Empiris pada Mahasiswa Universitas Muhammadiyah Surakarta dan Universitas Sebelas Maret). Skripsi Fakultas Ekonomi Dan Bisnis Program Studi Akuntansi Universitas Muhammadiyah Surakarta.

Lubis, A. I. (2014). Akuntansi Keperilakuan (2nd ed.). Jakarta: Salemba Empat.

Lunenburg, F. C. (2011). Expectancy Theory of Motivation: Motivating by Altering Expectations. International Journal of Management, Business, and Administration, 15(1), 1-6.

Martameh, M. S. (2012). Motivasi Sosial. Yogyakarta: Unversitas Gajah Mada. 
Menteri Keuangan Republik Indonesia. (2014). Peraturan Menteri Keuangan Republik Indonesia Nomor 25/PMK.01/2014 tentang Akuntan Beregister Negara, 1-36.

Menteri Keuangan Republik Indonesia. (2017). Peraturan Menteri Keuangan Republik Indonesia Nomor 216/PMK.01/2017 tentang Akuntan Beregister.

Minan, K. (2011). Pengaruh Motivasi Terhadap Minat Mahasiswa Akuntansi untuk Mengikuti PPAk (PPAk). Jurnal Keuangan \& Bisnis, 3(1), 37-48.

Noe, R. A., Noe, A. W., \& Bachhuber, J. A. (1990). An Investigation of the Correlates of Career Motivation. Journal of Vocational Behavior, 37, 340356.

Nurhayani, U. (2012). Pengaruh Motivasi Terhadap Minat Mahasiswa Akuntansi untuk Mengikuti PPAk (PPAk) (Studi Empiris pada Perguruan Tinggi Swasta Medan). Jurnal Mediasi, 4(1), 59-67.

Patrick, O. E., Ojeaga, \& Oseikhuemhen, J. (2011). Motivation, an Essential Ingredient for Optimal Performance in Emerging Markets. African Research Review, 5(18), 89-106.

Raminten. (2012). Pengaruh Motivasi Terhadap Minat Mahasiswa Akuntansi untuk Mengikuti PPAk (PPAk) (Studi Empiris pada Mahasiswa Program Studi S1 Akuntansi Universitas Semarang). JURAKSI, 1(2), 81-96.

Robbins, S. P., \& Judge, T. A. (2015). Perilaku Organisasi (16th ed.). Jakarta: Salemba Empat.

Saks, M. (2012). Defining a Profession: The Role of Knowledge and Expertise. Professions \& Professionalism Journal, 2(1), 1-10.

Schindler, L., Puls-Elvidge, S., Welzant, H., \& Crawford, L. (2015). Definitions of Quality in Higher Education: A Synthesis of the Literature. Higher Learning Research Communications, 5(3), 3-13.

Sirgy, M. J., Gurel-Atay, E., Webb, D., Cicic, M., Mehmedovic, M. H., Ekici, A., ... Johar, J. S. (2011). Is Materialism All That Bad? Effects on Satisfaction with Material Life, Life Satisfaction, and Economic Motivation. Social Indicators Research, 110(1), 349-366.

Sugiyono. (2014). Metode Penelitian Bisnis (Pendekatan Kuantitatif, Kualitatif, dan $R \& D)$. Bandung: Alfabeta.

Tella, A. (2007). The Impact of Motivation on Student's Academic Achievement 
and Learning Outcomes in Mathematics among Secondary School Students in Nigeria. Eurasia Journal of Mathematics, Science \& Technology Education, 3(2), 149-156.

Vansteenkiste, M., Soenens, B., Sierens, E., Luyckx, K., \& Lens, W. (2009). Motivational Profiles From a Self-Determination Perspective: The Quality of Motivation Matters. Journal of Educational Psychology, 101(3), 671-688.

Venugopalan, O. (2007). Theories of Motivation: Maslow's Theory of Motivation its Relevance and Application among Non-Managerial Employees of Selected Public and Provate Sector Undertakings in Kerala. Thesis Department of Commerce \& Management Studies University of Calicut, 3760 .

Vesperalis, A. A. A. D., \& RM, K. M. (2017). Pengaruh Motivasi pada Minat Sarjana Akuntansi Universitas Udayana untuk Mengikuti PPAk. E-Jurnal Akuntansi Universitas Udayana, 19(2), 1691-1718.

Wheeler, K. G. (1983). Perceptions of Labour Market Variables by College Student in Business, Education, and Psychology. Journal of Vocational Behavior, 22(2), 1-11.

Widyasari, Y., \& Laksito, H. (2010). Persepsi Mahasiswa Akuntansi Mengenai Faktor-Faktor yang Membedakan Pemilihan Karir (Studi pada Universitas Diponegoro dan UNIKA Soegijapranata). Skripsi Fakultas Ekonomi Universitas Diponegoro.

Widyastuti, S., \& Juliana. (2004). Pengaruh Motivasi terhadap Minat Mahasiswa Akuntansi untuk Mengikuti PPAk (PPAk). Simposim Nasional Akuntansi VII Denpasar,Bali.

Wyatt, A. R. (2003). Accounting Professionalism - They Just Don't Get It! Accounting Horizons, 18(1), 45-53.

Zyl, C. van, \& Villiers, C. de. (2011). Why some students choose to become chartered accountants (and others do not). Meditari Accountancy Research, 19(1/2), 56-74. 